\title{
APPLICABILITY OF SRI LANKA PUBLIC SECTOR ACCOUNTING STANDARDS: TRINCOMALEE URBAN COUNCIL, SRI LANKA
}

\author{
Nagalingam Nagendrakumar \\ Department of Business and Management Studies \\ Trincomalee Campus \\ Eastern University, Sri Lanka
}

\begin{abstract}
Though the Sri Lankan Local Governments were introduced with the accrual based Public Sector Accounting Standards from 2009 they have not been implemented yet. As a result, the present study focuses why it has been a failure and sees the applicability of the standards to the Local Governmental set up in Sri Lanka. The Urban Council of Trincomalee city was selected as the case for study and semi structured interviews were conducted. The study concludes that since the accounting system (Wickramanayake's accounting system) already in place was based on accrual principles, the application of accrual based accounting standards are possible provided that the staffs' professional expertise is improved to the level expected.
\end{abstract}

Keywords: Local Government, Sri Lanka Public Sector Accounting Standards Sri Lanka, Accrual Accounting

\section{Introduction}

Central Government, Provincial Governments (state governments/federal governments) and Local Governments are the key elements of the new public management domain. This is because of the bureaucratic relationship that links government to the universal provision of the service, and as such these elements can be relatively easily identified even though their nature may be different in diverse jurisdictions (Broadbent \& Guthrie, 2008). Certain recent developments that have taken place in different jurisdictions in the world demonstrate that the accounting profession, acting as a whole, has realized that the governmental accounting is an area that is important, meaningful and critical to the continuing growth of the nation (Harold, 1979). It must be remembered that all the professional study and pronouncements notwithstanding accounting reform will not take hold unless the Local Governments invest their resources in better accounting and recognize that not only the appropriate accounting principles are necessary for full disclosure but also that adherence to meaningful accounting principles enhances the fiscal discipline, provides more relevant information for better decision making, fosters systems efficiencies and lessens the likelihood that scare resources will be dissipated because of poor controls (Harold, 1979). In this aspect, the present study 
becomes significant since it tries to explain why the introduction of Sri Lanka Public Sector Accounting Standards (SLPSASs) to the Local Governments in Sri Lanka has failed and further, it scans the suitability of the such standards for Local Governmental jurisdiction in Sri Lanka employing Trincomalee Urban Council as the case.

\section{Literature review}

Financial Accounting is defined as information system, measurement methodology and communication system designed to produce selected financial quantitative data in a predisposed structure about an entity which engaged in economic activity during a particular period of time. American Accounting Association, 1966 defined the Financial Accounting as "the process of identifying, measuring, and communicating economic information to permit informed judgments and directions by users of the information". Accordingly, Ohlson and Zhang (1998) claim that accounting data summarizes the primitive transactions or events through accounting policies and standards with the purpose of preserving value-relevant information about the firm. Further, it could be noted that the financial accounting is an important technology of valuing, objectifying, organizing and reporting business and economic phenomena (Hoskin, 1994). As the consequence, it helps to permeate and shape organizational agendas, concerns and choices (Hopwood, 1984). In addition, accounting enables accountability, transparency and good governance to be operationalized through making organizational activities visible (Broadbent and Guthrie, 2008). Therefore,
Tower (1993) argues that accounting has an important impact on societal welfare because it promotes 'efficiency and equity' through the provision of accountability information transparently in the form of financial and nonfinancial reports to legitimate stakeholder groups. Thus, Antonio (1985) treats the public sector accounting and financial reporting as lances of Accountability, transparency and good governance. As a result, first, the Public Sector Accounting is the process of classifying, recording, and summarizing the myriad of financial transactions which a government regularly executes, and second, the Public Sector Financial Reporting refers to the way accounting information is displayed in the financial statements and all of the additional footnotes, supplementary schedules, and charts which can be included in the comprehensive annual financial reports of the Government.

Further, it is worth noting at this juncture those International Financial Reporting Standards (IFRSs) or the identical other standards (e.g. International Public Sector Accounting Standards (IPSASs) or Sri Lanka Accounting Standards (SLASs) or SLPSASs) are concreted on the concept of going concern and accrual. Saliya, (2012) advocates that these concepts, that have now become the fundamental assumptions of financial accounting, were already in existence millennia ago. Accounting has its basic foundation built in the concept of religion. Accordingly Saliya (2012) argues that religious concepts have been widely used to justify various historical social injustices. Four basic accounting principles; matching, accrual, going concern and reporting cycle perfectly correspond with human life cycle, the 
acts and rewards of such lives, and "balancing" the pains and gains of individuals and society. This is again proved since the 'innovator of the financial accounting especially the double entry' is said to be a monk (i.e., Luca Passioli). Therefore, it could be conveniently argued that the financial accounting is the result of social construction of a social reality which again to benefit the society.

It is interesting to note that both private and government sectors had been following the cash based accounting practices until 16th century with a thrust on single entry system (Al-husaini $\&$ Gowda, 2008). As a result, requirements to present financial statements to owners were almost unknown before 1800. The presentation of financial statements to the owners became common only from the $1820 \mathrm{~s}$. The format of presenting the financial statements to the owners and the stakeholders in the early days was based on cash-based receipts and payments accounts. Thus, it enabled the owners and the investors to determine the legitimacy of the dividend payments and it was called as the cash-based rate of return (McCartney, 2012).

However, the industrialization and resultant developments in the business sector paved the way for developments in accounting and financial reporting in the private sector though the government sector remained on the same cash based accounting system. As a result, the private sector developed and adopted accrual based accounting practices (Al-husaini \& Gowda, 2008). The major claim for such system changeover was that the cash basis of accounting practices does not provide information about total costs of an organization's activities whereas an accrual basis of accounting practices provides information on the total costs of resources used to deliver the organization's services, which is the essential information for decision makers (Al-husaini \& Gowda, 2008).

Overall, the financial accounting is broadly divided into cash accounting and accrual accounting. However, these methods differ only in the timing of the recognition of transactions. Under the traditional model of public administration, cash accounting, was initially considered as being more appropriate for the public sector. The emphasis of cash accounting was on compliance with rules, regulations and the budget. One of the results of this system is the budget out-turn report (i.e. the Annual Appropriation Account in Sri Lankan context) looked upon as a basic part of the usual financial statements in the public sector. The reason why it is called budget outturn report is that the public sector accounting and financial reporting is merely a carbon copy of the budget 'after its formal execution'. For that reason, sometimes the cash accounting is referred to as budgetary accounting or cameral accounting. According to the modern public administration model the emphasis has shifted from compliance to efficiency. As the consequence, it is argued that the public sector should be introduced with the set of accounting and financial reporting practices that are being applied in the private sector. Further, it could be argued that the public sector organizations can maximize the outcome by incorporating the competition enabling public management efficiency by achieving minimal costs for the society through the principle of the accrual accounting. Further, the 
balancing of the benefits from cash accounting and accrual accounting is much important in deciding whether a country needs financial reporting change.

In the above line of thinking, though scholars argue that the emphasis has moved from the compliance to the efficiency it cannot be blindly agreeable. In the earlier case (i.e. the application of cash accounting practices) the public sector complied with the rules and regulations of the relevant governments and under the modern shift (i.e. application of accounting standards), in addition to governmental financial rules and regulations, the Local Governments are expected to comply with the private sector accounting principles and standards. As a result, the shift from one to another has not made the difference in the emphasis but has made the improvement to the already existing concept of 'compliance' with more concern on 'efficiency'. This phenomenon has been the result of the 'net benefit' arising from the application of accrual accounting practices in the public sector organizations.

Many countries agree in principle that they have introduced IPSAS or IPSAS based indigenous standards (e.g. in Sri Lankan case SLPSASs) because it leads to world best practices. However, the pattern of adoption of IPSAS differs from country to country: First and foremost, not all but very few Governments have actually fully adopted the IPSASs, second, some countries initially introduced the cash based IPSAS and then tried to introduce the accrual based IPSASs, third, some countries introduced partially the accrual based IPSASs and then they moved on to full adoption, fourth, some countries initially introduced accrual based IPSASs to the Local Governments and then moved on to Central Government, and finally, some countries carried out rigorous research before adopting the accrual based IPSASs to find out its suitability before accepting or rejecting its application (e.g. Finland) (Oulasvirta, 2014). The main problem in applying the accrual based IPSASs is that the key requirement of producing consolidated financial statements for the entire nation (Wynne, 2003). However, it is argued that consolidating the financial statements of government business enterprises with the public entities would be very time consuming and almost all the Governments view that the result it yields does not worth the cost and the effort (Wynne, 2003).

Thus, some countries have not adopted the IFRSs or IPSASs in their jurisdictions (Oulasvirta, 2014; Jallow, 2008). Especially in developing countries, Government-owned institutions are dominant economic forces and as such require an efficient and effective Government financial management system (Jallow, 2008). Berry and Holzer (1993) cited in Jallow (2008) argue that the IFRS based accounting systems installed in those countries were often too sophisticated for local requirements because they were imported from developed jurisdictions to underdeveloped ones. But it could be noted that this argument is less relevant today's context because of globalization and thus the importance of IFRSs around the world has grown significantly (Jallow, 2008). However, the full adoption of them in all the jurisdictions across the world is debatable. 
Good governance is about the processes for making and implementing decisions. It's not about making 'correct' decisions, but about the best possible process for making those decisions. Good governance has a positive effect on various aspects of Local Governments including consultation policies and practices, meeting procedures, service quality protocols, Councilor and officer conduct, role clarification, good working relationships, and financial reporting. As a result, good governance is accountable, transparent, follows the rule of law, responsive, equitable and inclusive, effective and efficient and participatory (Karellacina, 2011).

There are three reasons why the quality of financial information is desirable in governmental accounting; first is to monitor and manage the performance, next is to entrust governments with the management of assets and liabilities that have been accumulated over decades, and finally a properly functioning democracy requires its people to have confidence in politicians and to be willing to take an interest in voting (Ball, 2005). The information that appears in the general purpose external financial statements is to meet the needs of the people interested in public sector activities (Miah, 1991). Users want an annual financial report, including what the government owes and what it owns, where its revenue came from and where they were spent, and including a report on the full cost of the programmes, generated using the same integrated accounting system that the rest of annual report is based on (Jones, 1992).

The historical review shows that the basic objective of financial statements is concerned with providing useful information for economic decision making and in addition, it emphasizes that information is useful when it shows economic reality of the financial statements and it is relevant and reliable to users (Shahwan, 2008). Mayston (1992) argues that each user group will have different questions to be answered and therefore, the process of preparing and presenting the financial statements should be promoted by existence of a well-defined interpretive framework that enables groups to understand the significant of financial reporting information in providing answers to the questions which are relevant to the particular group.

Politicization of accounting controls is aggravated in the public sector during colonization and even after independence in Sri Lanka. The operation of accounting controls in developing countries is politicized and therefore they are ineffective despite their worthy intentions (Hoque \& Hopper, 1994; Uddin \& Hopper, 2001; Wickramasinghe et al., 2004; Wickramasinghe \& Hopper, 2005; Uddin \& Tsamenyi, 2005; Allawattage \& Wickramasinghe, 2008). Trewavas et.al. (2012) provides additional evidence to Pilcher and Dean's (2009) argument that financial, political and social costs are associated with changing financial reporting requirements imposed on public sector entities, such as Local Governments.

\section{Research problem and questions}

From the preliminary study conducted by the researcheritwas found that thefinancial reporting system introduced to Local Governments has 
been based on Wickramanayake's reporting system and however, it has been criticized outdated. As a result, recent development in the public sector encourages the government organizations to follow SLPSASs. However, still the Local Governments have not switched on to the SLPSASs. This raises the research problem of why the Local Governments have not exposed to new developments in public sector accounting and financial reporting. This argument raises the following specific questions.

1. Is it due to incompetent accounting staff attached to Local Governments?

2. Is it due to unconscious institutionalization of Wickramanayake',s system in Local Governments?

3. Are the SLPSASs applicable to Local Governments?

\section{Purpose of the study}

This research aims to study and explain the applicability of SLPSASs to the Local Governments. Further, this research attempts to find out the reasons why the Local Governments have not yet introduced the SLPSASs.

\section{Method}

There is nearly universal agreement that science [that is, natural science] is a progressive discipline' (Losee, 2004). Depictions of the history of financial accounting research, too, are typically cast in progressive terms, often taking it for granted that the discipline is a social science, at any rate in its scholarly mode (Beattie, 2005). Further, the SLPSASs; the new system introduced to Local Governments and Wickramanayake's system; the old system which has been in operation in Local Governments for long period of time, are the outcome of human cognition and human action. As a result, it is argued that they are socially constructed realities for the betterment of the society. Hence, the philosophy of social constructionism, qualitative methodology, case study strategy has been employed to explain the research questions. Urban Council, Trincomalee was selected as the case for the study and three semi-structured interviews were conducted. The interviews were transcribed and coded. Further, thematic analysis (Braun \& Clarke, 2013) was carried out to come out with the common patterns of behaviour from the data set.

\section{Discussion}

The Australian public sector underwent a period of intense reforms including a comprehensive overhaul of financial reporting policies and major aspect of this reform was the involvement of the Australian Accounting Profession in the formulation of financial reporting standards (Ryan, Dunstan, \& Stanley, 1999). Similar mode of transformation is evident in Sri Lanka where the Institute of Chartered Accountants of Sri Lanka (ICASL) has become the major initiator of the public sector accounting and financial reporting reforms (Nagendrakumar, Fonseka \& Dissanayake, 2015a). Further, the United States federal government moved to accrual based accounting in 1997 and the GAAPs were adopted only by some state governments (Carpenter \& Feroz, 2001). However, in United States of America and Australia the transitory to accrual accounting occurred in 1997 but 
only in Central Government administration, in Local Government administration the change was implemented little later. In Sri Lankan context, this model has not been followed where the reform was first introduced to Local Governments and it has not been introduced to the Central Government yet (ICASL, 2009).

Canada took over the system in 2001-2002. However, it is argued that the adoption of IFRSs or IFRS based standards in public sector reporting in Canada and other countries such as Australia, NewZealand and the United Kingdom has been controversial (Pilcher \& Dean, 2009). Pilcher and Dean (2009a) found that IFRS requirements for Local Governments are time consuming and costly, adding little value to the management of Local Governments and often causing decoupling of internal and external financial reports. ICASL adopts the SLPSASs fully mimicked the IFRSs (Nagendrakumar, Fonseka \& Dissanayake, 2015). As a result, Sri Lanka also being the middle income country faces the constraints put forwarded by Pilcher and Dean (2009a). Moreover, Rixon and Faseruk (2009) found that it had an unexpected impact on public sector entities' financial statements due to a lack of detailed guidance for public sector entities since the Canadian entities used diverse interpretations of IFRS that led to non-comparable financial statements. Sri Lankan Local Governments also faces the identical problem since they have not been introduced the guidelines for preparation of the financial statements based on SLPSASs. $\mathrm{UC} / 01$ recorded this as,

"We have not been given the proper working manual for the preparation of the financial statements based on the SLPSASs"

Jones (1992) argues that the activities of the Local Governments are essentially determined by the law, rules and regulations for the financial controls of elected Councilors and, further, holds that even if the argument is widely acceptable, the precise role that the preparation and presentation of the financial statements play remains unexplained. Of course, The Sri Lankan Local Governments are also governed by the Urban Council Act No. 61 of 1939, Municipal Council Act No.16 of 1947, Village Council Act No.15 of 1987 and they are governed initially by the financial rules and orders of 1939. More to say, later, the Local Governments were introduced with the Wicramanayake's system for the preparation of financial statements which follows the accrual accounting principles but in limited aspects. Though the space is available for depreciation of fixed assets under the Wickramanayake's system it has not been followed. The reason for on-provision of depreciation is that the fixed assets management in Local Governments is very poor. Wickramanayake's reporting system is simply 'filling the form' prescribed and nothing involved with the 'principle based professional judgments' in the presentation of external financial reports.

Further, though the SLPSASs were introduced to the Local Governments by the ICASL it does not have the power of enforcing them to the government institutions including Local Governments (Nagendrakumar, Fonseka \& Dissanayake, 2015). However, Treasury and the Ministry of Provincial Councils and Local Governments have issued circulars to 
adopt the SLPSASs. Yet, the practicing part of SLPSASs by Local Governments has become doubtful. UC/01 record this as,

"Still the SLPSASs have not been implemented in the Local Governments and Auditors are used to raise the queries on non-application of the standards"

It is due to the fact that the Local Governments are governed by the relevant Acts of Parliament and therefore, it is argued that any major change in the operation of the Local governments need amendment to the particular Act which has not happened yet. $\mathrm{UC} / 01$ records this as,

"How we can implement without amending the act or Cabinet Decision?"

Continued lack of progress is reported in public sector accounting and financial reporting reforms, in Indonesia. This was due to the fact that first, the existence of lack of interest in and understanding of the issues among politicians, next, successive governments had been reluctant to push hard for accounting reforms because improved accountability poses a significant threat to politicians' and bureaucrats' overall income levels, and finally, human resource management practices in the public sector have resulted ina shortage of accounting skills(Harun, 2007). The Eastern Provincial Government (one of the nine provincial Governments in Sri Lanka) where the present case study was undertaken operates 03 Municipal Councils, 05 Urban Councils and 37 Village Councils. Among the 45 Local Governments only the Municipal Councils and the Urban Councils have been allocated the Accountants cadre. Furthermore, only two Municipal Councils have been assigned the Accountants, one has been assigned the Accountant on acting basis, and all the Urban Councils and Village Councils have been functioning without the Accountants. As a result, the Urban Councils and Village Councils have been managed by Financial Assistants or Development Officers/ Finance. Thus it is argued that most of the Local Governments are managed without the qualified Accountants. This has become the major barrier in implementing the SLPSASs in the Local Governments in Sri Lanka.

In addition, Local Governments have been used to Wickramnayake's system of accounting. As a result, Wickramnayake's format has become the 'Bible' for the Financial Assistants in the Local Governments in preparing and presenting the final accounts. As such, the Local Governments have been unconsciously institutionalized to the rule based system. If reforms needs some more moves beyond Wickramnayake's manual then certain directives or the guidelines should be developed by the hierarchy and it needs to be gazzested (i.e., the formal Government order).

Due the above shortcoming, the introduction of the public sector accounting and financial reporting reforms in the entire public sector has not been very clear: Some organizations have adopted the accrual accounting principles and the SLPSASs (e.g. Statutory Boards), some have adopted the accrual accounting principles but not the SLPSASs (e.g. Local Governments), some have been following the accrual accounting on pilot basis and have not adopted the SLPSASs (e.g. some ministries and departments) and the rest of the public sector organizations have ignored the accrual 
accounting practices at all and confined to the traditional cash accounting practices.

Notwithstanding of failure of the adoption of accounting standards in the Local Governments it is argued that the SLPSASs are applicable to them since it is well in line with the Wickramanayake's accounting system, that is, both are based on accrual principles. UC/01 recorded this as,

"Adopting the SLPSASs to the UC is not a problem"

Further, it is worth noting that a committee formed under the Ministry of Finance-Asian Development Bank- Financial Management Training Programme during 1990s examined the relevancy of SLASs to Municipal Councils setup in Sri Lanka and the committee recommended the following SLASs as relevant.

SLAS-3: Disclosure of accounting policies,

SLAS-5: Inventories,

SLAS-8: Accounting for depreciation,

SLAS-9: Cash flow statements,

SLAS-10: Net profit or loss for the period, fundamental errors and changes in accounting policies,

SLAS-11: Research and development costs,

SLAS- 12: Contingencies and events occurring after the balance sheet date,

SLAS-13: Construction contracts,

SLAS-15: Presentation of current assets and current liabilities, SLAS-18: Property plant and equipment,

SLAS-20: Borrowing costs,
SLAS-21: The effects of changes in foreign exchange rates,

SLAS-22: Accounting for investments,

SLAS-24: Accounting for government grants and disclosure of government assistance, SLAS-25: Business combinations,

SLAS-29: Revenue, and

SLAS-31: Financial reporting of interest in joint ventures.

However, the recommendations of the committee were not implemented in the Municipal Councils. The introduction of SLPSASs to the Local Governments again in 2009 was similar in nature since SLPSASs are based on SLASs. Therefore, it is argued that the failure of implementation of SLPSASs occurred not because of the applicability of the standards but because of the way that was introduced to the system.

\section{Conclusion}

Wicramanayake's system of accounting has been based on accrual basis. Further, the SLPSASs also have been based on accrual basis. The difference between the two is that former is rule based and the latter is principle based. As a result, the SLPSASs are advisable to be practiced by the Local Governments provided that the Local Governments are provided with the professional skills since of the need for knowledge in professional judgments under the principle based system of SLPSASs. Further, The Local Governments need to be apportioned with the Accountants cadres and assigned with the Accountants in reality to transit the system from Wicramanayake's to SLPSASs. Moreover, 
the Government needs to recognize the importance of the transparency, accountability and good governance of the local jurisdictions and make the SLPSASs a necessary ingredient in financial reporting by gazzette notification. Further, the Ministry of Finance and Ministry of Provincial Council and Local Governments jointly need to introduce the guidelines for incorporation of the SLPSASs in the Local Government set up by passing the required amendments to the relevant Acts of Parliament in the country.

\section{References}

Alawattage C. \& Wickramasinghe, D. (2008). Appearance of Accounting in a Political Hegemony. Critical Perspectives on Accounting, 19(3), 293-339.

Al-husaini, M. \& Gowda, K. N. (2008). The Conceptual Framework of Accrual Accounting as Applicable to Government Activities. The Icfai University Journal of Accounting Research, 7(3), 59-68.

American Accounting Association, Committee to Prepare a Statement of Basic Accounting Theory. (1966). A Statement of Basic Accounting Theory. [Evanston, Ill.] American Accounting Association publication.

Antonio, J.F. (1985). Role and Future of the Government Accounting Standards Board. Public Budget and Finance, (Summer), 3038.

Beattie, V. (2002). 'Traditions of research in financial accounting'. In Ryan, R., Scapens, R. W. and Theobald, M. (eds.). Research Method and Methodology in Finance and Accounting, 2nd edn. London: Thomson, 94-113.
Braun, V. \& Clarke, V. (2013). Successful Qualitative Research: A Practical Guide for Beginners. Sage Publication, New Delhi.

Broadbent, J. \& Guthrie, J. (2008). Public sector to public services: 20 years of "contextual" accounting research. Accounting, Auditing \& Accountability Journal, 21(2), 129-169.

Harold, I.S. (1979). A New Look at Governmental Accounting. Journal of Accounting, (March), 46-55.

Carpenter, V. L., \& Feroz, E. H. (2001). Institutional Theory and Accounting Rule Choice: An Analysis of Four US State Governments' Decisions to Adopt Generally Accepted Accounting Principles. Accounting, Organizations and Society, 26(7-8), 565-596.

Harun. H. (2007). Obstacles to Public Sector Accounting Reform in Indonesia. Bulletin of Indonesian Economic Studies, 43(3), 365-375.

Hopwood, A. (1984), Accounting and the Pursuit of Efficiency in "Issues in Public Sector Accounting", A. Hopwood and C. Tomkins (eds.), Pitman, 167-187.

Hoque ,Z. \& Hopper, T. (1994), Rationality. Accounting and Politics: A Case Study of Management Control in a Bangladeshi Jute Mill, Management Accounting Research, 5, 5-30.

Hoskin, K. (1994). Boxing Clever: For, Against and Beyond Foucault in the Battle for Accounting Theory. Critical Perspectives on Accounting. 5(1), $57-85$. 
Institute of Chartered Accountants of Sri Lanka, (2009). Sri Lanka Public Sector Accounting Standards, Colombo.

Jallow, P. (2008). A Historical Analysis of the Accounting Development in Madagascar between 1900 to 2005: The Journey from Accounting Plan to IFRS. Journal of Applied Accounting Research, 9(2), 126144.

Jones, R. (1992). The Development of Conceptual Frame Works of Accounting for The Public Sector. Financial accountability and Management, 8(4), 249-264.

Karellacina. (2011). Remarks to the Development of Public Administration from the Concept of "Government" to the Concept of "Governance". ACTA, (5), 126-149.

Losee, J. (2004). The Theories of Scientific

Progress. Routledge, New York.

Mayston, D. (1992). Capital Accounting, User

Needs and the Foundations of a Conceptual Frame Work for Public Sector Financial Reporting. Financial Accountability and Management, 8(4), 227-248.

McCartney, S. \& Arnold, A.J. (2012). Financial Capitalism, Incorporation and the Emergence of Financial Reporting Information Accounting, Auditing and Accountability Journal. 25 (8), 1290-1316.

Nagendrakumar, N., Fonseka, M., and Dissanayake, K. (2015). The Development of Public Sector Accounting and Financial Reporting in Sri Lanka. International Journal of Governmental Financial Management, XV(2),70-88.
Nagendrakumar, N., Fonseka, M., \& Dissanayake, K. (2015a). Do Institutional Pressures Matter in Development? A case of Introduction of Accrual Accounting Practices to the Public Sector in Sri Lanka. The 10th International Research Conference on Management and Finance, Faculty of Management and Finance, University of Colombo, (November), 3039.

Ohlson, J.A and Zhang, X. (1998). Accrual Accounting and Equity Valuation. Journal of Accounting Research, 36 (Supplement), $85-111$.

Oulasvirta, L. (2014).The Reluctance of a Developed Country to Choose International Public Sector Accounting Standards of the IFAC: A Critical Case Study. Critical Perspectives on Accounting, 25, 272-285.

Pilcher, R \& Dean, G. (2009). Consequences and Cost of Financial Reporting Compliance for Local Government. European Accounting Review, 18(4), 72544.

Pilcher, R. \& Dean, G. (2009a). Implementing IFRS in Local Government: Value Adding or Additional Pain? Qualitative Research in Accounting and Management, 6(3), 180-96.

Rixon, D. \& Faseruk, A. (2009). Valuation in Public Sector Agencies: Impact on Financial Reporting through the Implementation of International Financial Reporting Standards: Focus on Canadian Workers Compensation Boards. Journal of Financial Management and Analysis, 22(1), 16-27. 
Ryan, C., Dunstan, K. \& Stanley, T. (1999). Constituents Participation in the Australian Public Sector Accounting Standards Setting Process : The Case of ED 55. Financial Accountability and Management, 15(2), 173-200.

Saliya, C. (2012). The Oldest Profession. Accounting, Auditing and Accountability Journal, 25(6), 1072.

Shahwan, Y. (2008). Qualitative Characteristics of Financial Reporting: A Historical Perspective. Journal of Applied Accounting Research, 9 (3), 192-202.

Tower, G. (1993). A Public Accountability Model of Accounting Regulation. British Accounting Review, 25(1), $61-86$.

Trewavas, K. and Redmayne, N.B. and Laswad, F. (2012). The Impact of IFRS Adoption on Public Sector Financial Statements. Australian Accounting Review, 60, 22(1), 86-102.
Uddin., S, Hopper, T. (2001), A Bangladesh Shop Opera: Privatisation, Accounting, and Regimes of Control in a Less Developed Country ${ }^{\circ}$, Accounting, Organizations and Society, 26, 643-672.

Uddin, S. and Tsamenyi, M. (2005). Public Sector Reforms and Public Interest. Accounting, Accountability and Auditing Journal, 18(5), 648-674.

Wickramasinghe, D., Hopper, T., \& Ratnasiri, C. (2004). Japanese Cost Management Meets Sri Lankan Politics: Disappearance and Reappearance of Bureaucratic Controls in a Privatized Utility. Accounting, Auditing and Accountability Journal, Vol. 17, No. 1

Wickramasinghe, D. \& Hopper, T. (2005), A Cultural Political Economy of Management Accounting Controls: A Case Study of a Textile Mill in a Traditional Sinhalese village. Critical Perspectives on Accounting, 16, 473-503. 